\title{
Strates
}

STRATES Matériaux pour la recherche en sciences sociales

$1 \mid 1986$

Mélanges

\section{Tableau chronologique de l'aménagement rural en France (1950-1985)}

\section{Yves Luginbühl}

\section{(2) OpenEdition}

1 Journals

Édition électronique

URL : http://journals.openedition.org/strates/355

DOI : $10.4000 /$ strates.355

ISSN : $1777-5442$

Éditeur

Laboratoire Ladyss

Édition imprimée

Date de publication : 1 janvier 1986

ISSN : 0768-8067

\section{Référence électronique}

Yves Luginbühl, « Tableau chronologique de l'aménagement rural en France (1950-1985) », Strates [En ligne], 1 | 1986, mis en ligne le 08 décembre 2004, consulté le 08 septembre 2020. URL : http:// journals.openedition.org/strates/355; DOI : https://doi.org/10.4000/strates.355

Ce document a été généré automatiquement le 8 septembre 2020.

Tous droits réservés 
Tableau chronologique de l'aménagement rural en France (1950-1985)

Yves Luginbühl 